\title{
Exploratory Analysis of the Shopping Orientation in the Tunisian Context
}

\author{
Mohamed Mejri ${ }^{1}$, Mohsen Debabi $^{2} \&$ Khaled Nasraoui $^{3}$ \\ ${ }^{1}$ Department of Economic and Management, University of Littoral, Dunkerque, France \\ ${ }^{2}$ Department of Management, Ecole Supérieure de Commerce de Tunis, Université de La Manouba, Tunis, \\ Tunisia \\ ${ }^{3}$ Department of Management, Ecole Supérieure de Commerce Eléctronique de Tunis, Université de La Manouba, \\ Tunis, Tunisia \\ Correspondence: Mohamed Mejri, Department of Economic and Management, University of Littoral, Dunkerque, \\ France. E-mail: mohamed.mejri@univ-littoral.fr
}

Received: April 19, 2012 Accepted: May 1, 2012 Online Published: September 10, 2012

doi:10.5539/ijms.v4n5p1 URL: http://dx.doi.org/10.5539/ijms.v4n5p1

\begin{abstract}
On the basis of a research conducted within a Tunisian context and through a large survey made up of 600 shoppers, this research aims to enhance the shopping orientation literature. The findings highlight two main points: (1) the predominance of utilitarian motivation at the expense of experiential ones and (2) the identification of a typology resetting on four shopping trips classes: the planned shopping trip, the recreational shopping trip, the lights fill-in shopping trip, and the ordinary fill-in shopping trip. Consequently and in the light of the shopping trip types and the socio-demographic shoppers factor, our research attempt to advance a Tunisian shoppers' profile typology.
\end{abstract}

Keywords: shopping behavior, shopping trip, shopping motivations, correspondence analysis

\section{Introduction}

Since the pioneer research of Stone's (1954), an overview of the literature impels for revealing the importance of the shopping orientation from an academic and managerial perspective.

Indeed, too many scholars including Kahn \& Schmittlein (1989, 1992), Kaltcheva \& Weitz (2006), and Nordfalt (2009) have reported that the shopping trip influences the consumers' in-store behaviour. The shoppers, usually, tend to attend store in which they are more likely to meet their expectations. Other works such as those advanced by Shim \& Kotsiopulos (1992), Darden \& Howell (1987), Gutman \& Mills (1982), Bellenger \& Korgaonkar (1980) and Darden (1980) have heralded that the shopping orientations is among the factors that affect the patronage behavior.

In the light of the previous findings, the shopping orientation seems of central importance to examining and understanding shopping behavior for both academics and practitioners in terms of developing strategies and tactics contingent upon the shopping orientations of their customers.

Different aspects of shopping orientation have been studied. While a stream of literature has focused mainly on the shopping trip and suggested many typologies of shopping trip (Allard, Babin \& Chebat, 2009; Anic \& Radas, 2006; Babin, Darden \& Griffin, 1994; Carpenter \& Moore ,2009; Dawson, Bloch \& Ridgway, 1990; Kahn \& Schmittlein, 1992; Walters \& Jamil, 2003; Westbrook \& Black, 1985), several other researchers have investigated the motives and/or the factors that may explain the consumers shopping orientation (Arnold \& Reynolds, 2003; Carpenter \& Moore, 2009; Chen \& Hsieh, 2011; Dawson \& al, 1990; Fox, Montgomery \& Lodih, 2004; González-Benito et al., 2007; Geuens et al, 2002; Groeppel et al. ,1999; Karande \& Ganesh, 2000; Kim, 2005; Tauber 1972; Ibrahim \& Wee, 2002; Westbrook \& Black, 1985). Others scholars have put more emphasis on describing the shoppers' profiles (Anic \& Vouk, 2005; Boedeker, 1995; Carpenter \& Moore, 2009; Darden \& Reynolds, 1971; Geuens et al., 2001; Kuruvilla \& Joshi, 2010; Lesser \& Hughes, 1986).

This study aims to explore the shopping orientation within the Tunisian context. To meet this purpose, we will first explore the shopping trip of Tunisian shoppers according to many factors such as motives, time devoted and 
regularity of the shopping activity. Thereafter, we will attempt build a shoppers typology based upon the shopping orientation as well as the socio-demographic features of the Tunisian shoppers.

The remainder of the paper is organized as follows: the first section reviews most of the important shopping orientation works advanced by the literature. The second section describes the adopted methodology as for the third section, it highlights the main results. The final section is dedicated to discuss the main findings extracted by this research.

\section{Literature Review}

The concept of shopping orientation has been widely investigated by researchers from various perspectives. Despite the wide interest attached to this concept, it has stirred up a controversy in the literature, mainly in terms of complexity and multidimensionality (Visser \& du Preez, 2001).

In term of the nature of the shopping orientation, researchers have proposed various definition of the concept, but to date, none seems to be subject of an unanimity. The first advanced definition was given by Stone (1954), who has considered the shopping orientation as a shopping lifestyle or shopper's style encompassing shopping activities, interests and opinions. Visser \& du Preez (2001) argued that the concept is extremely difficult to be defined due to numerous interrelated variables. These same authors have also stated that the literature reports a weak consideration of some important concepts (or variables) as for the definition of the concept. They have also concluded that the concept of shopping orientation consists of "a personal dimension (e.g. activities, interests, opinions, motives, needs and preferences) and a market behaviour dimension or a general approach to acquiring goods and services. This market behaviour dimension reflects the personal dimension and indicates needs and preferences for, inter alia, information sources, stores per se (patronage behaviour) and store attributes (including store image)". More recently, Hassan, Muhammad \& Bakar (2010) consider simply that this concept is related to general predisposition toward acts of shopping.

\subsection{The Shopping Trip}

The shopping trip was and still one of the main elements related to the shopping orientation issue. Through this subsection, we will go through the common and most important works advanced by the literature and mainly within the marketing field.

One of the main facts impelled by the literature resets on the distinction between utilitarian/economic shopping and recreational/hedonic shopping (Allard, Babin \& Chebat, 2009; Babin, Darden \& Griffin, 1994; Bellenger \& Korgaonkar, 1980; Dawson, Bloch \& Ridgway, 1990; Falk \& Campbell, 1997; Jones et al, 2006; Westbrook \& Black, 1985). The utilitarian shopping is neared as a goal-oriented, efficient, rational, and deliberating (Babin, Darden \& Griffen, 1994) that concerns the daily use product often seen by the shopper as a "task" (Babin, Darden \& Griffen, 1994) or even a chore. Unlike, utilitarian shopping is primarily functional, regularly proceeded and providing no relaxation or enjoyment states. In contrast, recreational or hedonic shopping is specifically viewed by the shopper as a fun activity (Babin, Darden \& Griffen, 1994), a form of escape and, thus, affording an enjoyment feeling (Falk \& Campbell, 1997) calling more for leisure than work.

Others authors differentiate between major shopping trips and fill-in shopping trips (Anic \& Radas, 2006; Kollat \& Willett, 1967; Kahn \& Schmittlein, 1992; Walters \& Jamil, 2003). The major trips are usually related to household items and aims to meet short and long-term needs (Walters \& Jamil, 200). They are regular and require much time, effort and money. Fill-in trips, in contrast, are rather a complementary shopping trip that are made to solve an urgent need (Nordfalt, 2009) or to make purchases for a less common situation, (Kahn and Schmittlein, 1989; Walters \& Jamil, 2003) and, thus, require less time and money and more intelligence.

Others shopping form were also suggested in the marketing field, such as the browsing behavior (Bloch \& Richins, 1983; Bloch, Ridgway \& Nelson, 1991; Bloch, Ridgway \& Sherrell, 1989; MacInnis \& Price, 1987) or the cross-shopping behavior (Carpenter \& Moore, 2009; Cassiil \& Williamson ,1994; Skallerud et al. ,2009; Miller et al.,1999; Schoenbacher \& Gordon , 2002). Browsing behavior is a specific form of shopping behavior which can occur independently of specific purchase occasions and is both a form of leisure activity and a form of external search behaviour (Bloch \& Richins, 1983). It is the examination of a store's merchandise for recreational or informational purposes without a current intent to buy. Browsing behavior is positively related to the product involvement (Bloch \& Richins, 1983; Bloch, Ridgway \& Sherrell, 1989) and could be as pleasant as product buying since it is a product virtual cunsumption (MacInnis \& Price, 1987). Cross-shopping behavior refers to consumer shopping for products in different types of retail format (Carpenter \& Moore, 2009). Cassill \& Williamson (1994) defined Cross-shopping as a single customer patronising multiple types of outlets, which hold the same broad merchandise lines. However, Miller et al. (1999) and Schoenbacher \& Gordon (2002) defined 
cross-shopping behaviour as circumstances in which customers purchase goods through multiple channels run by the same retailer.

It should be also noted that the literature has also proposed, through a retailer's perspective (Hansen, 2003; Miller et al., 1999), two types of behaviours: The intra-type crossing and the inter-type crossing. The intra-type crossing refers to crossing between the same types of outlets (i.e. crossing from one supermarket to another supermarket). The inter-type crossing is more about crossing between different types of outlets (i.e. crossing from a supermarket to a speciality store).

\subsection{Antecedents of Shopping Orientation}

The literature of shopping orientations revealed that shoppers with different orientations have different characteristics, motivations, demographics and different personal characteristics. It was also reported that shoppers are subject to influences exercised by the store attributes.

\subsubsection{Shopping Motivations}

Marketing and retailing literature has early demonstrated the diversity of shopping motivations (Anic \& Vouk, 2005; Arnold, Oum \& Tigert, 1983; Arnold \& Reynolds, 2003; Dawson \& al, 1990; Geuens et al, 2002; Groeppel et al. 1999; Karande \& Ganesh, 2000, Tauber 1972; Westbrook \& Black, 1985 ...). Westbrook \& Black (1985) stated that shopping motives can be independent of products to be purchased, representing "enduring characteristics of individuals" that can be also interpreted as "person-specific causes of involvement".

Tauber (1972) was, to our knowledge, the pioneer in studying shopping motives. An explorative study allowed him to conclude that consumers' shopping is often driven by personal and social motives. The personal motives are explained by a diversion from the routine of daily life, self-satisfaction and sensory stimulation. As for the social motives, they are about social experience outside the home, peer group attraction and bargaining pleasure.

Westbrook \& Black (1985) identified seven shopping motives, called "anticipated utility", "role enactment", "negotiation", "choice optimization", "affiliation", "power and authority" \& "stimulation".

Early researchers assume that shoppers motivations are mainly utilitarian or hedonic (Babin, Darden \& Griffin, 1994; Bellenger \& Korgaonkar 1980; Dawson et al., 1990; Westbrook \& Black 1985). According to Babin, Dardin, \& Griffin (1994), when shoppers' motives are utilitarian, shopping is task-oriented and rational. Shoppers are qualified as functional or economic seekers and their shopping is neared as a work-task. Kim (2006) adds that utilitarian motivation include two dimensions; efficiency and achievement. Efficiency refers to consumer needs and goal to save time and resources, while achievement is more concerned about the shopping goal embodied in the success in finding specific products.

To the contrary, hedonic motivations are associated with the hedonic needs of shoppers that view shopping activity as a positive experience that can make shoppers enjoy an emotionally satisfying experience regardless of whether or not a purchase was made. Arnold \& Reynolds (2003) conceptualized the hedonic motivations with six dimensions called adventure, social, gratification, idea, role, and value.

Recently, on the basis of an extensive literature review, Geuens et al. (2002) conclude that there are three types of shopping motivations: functional, social and experiential / hedonic motivations. Functional motivations are related to tangible elements such as product assortment, product quality and price; social motivations are those that reflect the need to communicate and interact with others and share similar interests, where Experiential / hedonic motivations are those that stimulate the senses of the shopper and his desire to live a new experience.

The authors add that the importance of each motivation is contingent upon the personality of the shopper, situational factors, the product category and the shape of distribution.

\subsubsection{Demographic Characteristics of the Shoppers}

Scholars used demographics to study different aspect of shopping behavior. Some of them have examined the relationships between demographic characteristics of shoppers and the retail format choice. For example, Crask \& Reynolds (1978) and on the basis of a comparison between the demographic profiles of frequent and non-frequent department store patrons, they have found that frequent patrons are younger, more educated and have higher incomes.

Others researchers have studied the link between shopping motivations and the shoppers demographic characteristics. Groeppel-Klein, Thelen \& Antretter (1999) examined the link between three shoppers clusters (stimulation seekers, "advice-oriented consumers" and "price-oriented consumers") and demographic indicators. They have reported no significant difference among the obtained three clusters. Arnold \& Reynolds (2003) found that females are more likely to emphasize on hedonic value than males insofar as they have stronger 
hedonic shopping motivations. Ibrahim and Wee (2002) found that differences in term of hedonic motivations occur in marital status, age, occupation, transport ownership and gender, however, differences in "utilitarian oriented" occurs only in occupation and gender.

Another research elaborated by Cassiil \& Williamson (1994) has focused on the relationships between cross shopping behavior and the demographic characteristics of the shoppers. The authors have reported significant differences between department store cross shoppers and non-cross-shoppers based on age, household size, annual spending, marital status, employment status, and occupation. Cross-shoppers of the three types of department stores examined in the study (traditional, national chain, discount) tend to be older and not employed outside the home. In contrast, cross-shoppers of national chain and discount department stores tend to be younger and have a large household size.

Recently, Fox, Montgomery \& Lodih (2004) and through a study across three store formats (grocery stores, mass merchandisers stores and drug stores), have found that household size, income and education level influence the consumers choice of retail format. They have also mentioned that education and income do not appear to affect the number of stores visited during a shopping trip.

Finally, Carpenter \& Moore (2009) found that gender, race and marital status influence the Cross-shopping behavior. While male tend to adopt the "within departement store" cross-shopping, female tend to adopt "the departement/discount" one. The authors also found that Caucasians are more likely to adopt the "within departement store" cross-shopping more than the African-American who are more concerned about discount shop cross shopping than Caucasians.

These two authors have also stated that shopping clusters differ based on marital status. Married tend to adopt "within departement store" cross-shopping more than singles, while divorced and widowed are more likely to adopt "discount" cross-shopping more than singles, whose tend to adopt the "upscale speciality" cross-shopping more than married.

\subsubsection{Shoppers' Personal Characteristics}

Many shoppers' personal characteristics have examined in the shopping orientation, such as personal values, personality traits, religiosity, etc.

Homer \& Kahle (1988) found that, of three personal value dimensions measured by the List of Value (LOV) scale, two were positively related to favorable attitudes toward natural food shopping: a self-actualizing value dimension (i.e., self-fulfillment, sense of accomplishment and self-respect) and a social affiliation dimension (i.e., fun and enjoyment and friendly relationships). Shim \& Eastlick (1998) demonstrated that self-actualizing and social affiliation personal values were positively related to a favorable attitude toward regional shopping malls, and that the social affiliation value played a greater role in influencing attitude than did the self-actualizing value Swinyard (1998) focuses on the values of mall shoppers, using the List of Values (LOV) and found that frequent mall shoppers have higher needs than others for "sense of belonging", "warm relationships", and "security". Their needs are also higher for "excitement". It is hypothesized that needs for "self-fulfillment", "self-respect", and a "sense of accomplishment" are negatively related to mall-visit-frequency; a result partially supported by the data.

As for personnaliy traits, Guido (2006) used the Big Five model and demonstrated that openness to experience, agreeableness and extroversion traits are correlated to the hedonic shopping, whereas emotional stability, and conscientiousness traits are connected to the utilitarian shopping value.

Finally, Mokhlis (2006) investigated the effect of religiosity on consumers' shopping orientations in the Malaysian context and found that religiosity should be considered as a possible determinant of shopping orientations in consumer behavior model.

Jianfeng, Hongping \& Lanying (2009) tested the shopping behavior (related to mobile phone) of Christians in China and concluded that a kind of shopper, namely trend shopper is consistently related to religiosity. The authors suggested that religiosity should be considered as a possible determinant of shopping behavior in the future.

\subsubsection{Stores' Attributes}

Several studies in retailing pointed out that stores attributes affect the consumer's store selection (Carpenter, 2008; Darian, Tucci \& Wiman, 2001; Fox et al, 2004; González-Benito et al., 2007; Kolodinsky \& Cranwell, 2000; Morganosky, 1997; Moschis et al, 2004; Oates, Shufeldt \& Vaught, 1996; Rhee \& Jeon, 2001; Seiders \& Tigert, 2000). 
Some researchers found that store location, which mainly includes customers' accessibility to the store as well as others factors such as distance and time, plays an important part in determining the choice of the store (Fox et al, 2004; Kolodinsky \& Cranwell, 2000). Some shoppers prefer to shop at convenient and easy access stores (Fox et al, 2004; Moschis et al, 2004). González-Benito et al. (2007) go far and asserted that distance is the primary criterion for store choice.

Shoppers' preferences are also affected by the product assortment and the customers' perception of product variety (Carpenter, 2008; Morganosky, 1997; Seiders \& Tigert, 2000), in that they are looking to satisfy as many shopping needs as possible when visiting the same store (Carpenter, 2008). Fox et al, 2004, have demonstrated that consumers switch stores to benefit from temporary promotional offers. Carpenter \& Moore (2009) found that promotion help to build patronage and store traffic; while Ruiz \& Descales, (2008) fount that they can even affect sales of other items.

As for Service' attributes, Oates, Shufeldt \& Vaught (1996) found that Service attributes (relating to delivery, phone-in, carry-out, and parking) are not key considerations for shoppers. Darian, Tucci \&. Wiman (2001) investigated the impact of selected salesperson service attributes and levels on consumer patronage intentions in a consumer electronics store setting and concluded that salesperson's respect for the customer, knowledge, and responsiveness are the most important attributes. The authors suggested that retailers do not necessarily have to offer the best service levels to satisfy customers, but must avoid poor service levels. Unlike, Rhee \& Jeon (2001) and through a research conducted in South Korea, they have found that service quality (ability of salespeople, belief in policy, convenience of facility, convenience of using credit cards and appearance of salespeople) influence store patronage behavior.

At last, some authors (for example Donaven et al., 1994) have reported that store environment and store atmosphere (which include the exterior of the stores like the storefront, entrances, display windows, building architecture, parking facilities, and the surrounding areas, as well as the general interior variables and human variables) are influential retail attributes. Store atmospheric factors will affect not only shopper emotions but also customer cognitive valuations of store commodities and services (Chen \& Hsieh, 2011) as well as patronage intention (Baker et al, 2002).

\subsection{Shoppers' Profiles}

To investigate the shopping behavior and on the basis of many discriminant variables such as shopping orientation, shopping motives, personal, situational and socio-demographic characteristics of the shoppers, many scholars have suggested various typologies of shoppers.

At our knowledge, the first shoppers' taxonomy was proposed by Stone (1954). Shoppers were split up into four types, called the economic shopper, the personalizing shopper, the ethical shopper and the apathetic shopper. The economic shoppers are those who pay more attention to merchandise assortment, price and quality. The personalizing shoppers are more concerned about personal relationships with salespeople while the ethical shoppers are those who support local stores sometimes at the expense of prices and goods variety. Finally, the apathetic shoppers are those who aren't interested in shopping but does shopping because of necessity.

Since stone (1951) seminal research, numerous other versions of shopper classification have been made (Anic \& Vouk, 2005; Boedeker, 1995; Carpenter \& Moore, 2009; Darden \& Reynolds, 1971; Geuens et al., 2002; Kuruvilla \& Joshi, 2010; Lesser \& Hughes, 1986).

Darden and Reynolds (1971) replicating Stone's research, proposed a four-classes typology of shoppers and distinguish between the economic shoppers, the apathetic shopper, personalizing shoppers, ethical shoppers. Lesser \& Hughes (1986) identified seven different king of shoppers, called Inactive shoppers, Active, Service, Traditional, Dedicated fringe, Price shoppers and Transitional shoppers.

On the basis of three variables named the time allocated by the shoppers to the shopping trip (time-poor or time-rich), the importance they placed on social interactions and the degree of importance of the experiential elements, Geuens et al. (2002) have extracted six different segments: convenience shoppers (time-poor, no social nor experiential interest), low-price shoppers (time-rich, neither social nor experiential interest), social shoppers (time-poor, social but no experiential interest), intense social shoppers (time-rich, social but no experiential interest), experiential shoppers (time-poor, experiential interest) and recreational shoppers (time-rich, experiential interest).

Anic \& Vouk (2005) suggested a four-group typology of shoppers with significant different wants and purchasing behavior, called respectively, price-driven shoppers, convenience-oriented shoppers, rental involved shoppers and driven shoppers. 
The price-driven shoppers are the least loyal shoppers and rated low prices as the most important store patronage motive factor. The convenience-oriented shoppers are willing to trade off convenience for higher prices. The location-driven shoppers considered convenient store location to be the most important store choice factor, (followed by shoppingconvenience and in-store stimuli), as for the involved shoppers, they are more looking for the lowest prices and very high level of convenience and are the most demanding shoppers.

Recently, on the basis of a distinction between cross shoppers (consumers shopping for products in different types of retail format) and single-format shoppers, Carpenter \& Moore (2009) suggest a four clusters shoppers typologies. Department store cross-shoppers, which is a group of consumers that tend to cross-shop for apparel in traditional and value department stores. Discount cross-shoppers qualified as a group that is more willing to shop for clothing at discounters. The department/discount cross-shoppers that is a group that tend to cross-shop in a value department stores and discounters and the upscale/specialty cross-shoppers is a group that is more likely to cross-shop in up-scale department store and specialty stores.

Finally, the study of shoppers' profiles has never been a subject of scholars' unanimity. The discrepancies result from many factors such as the variables used to classify the shoppers, the methodologies adopted by researchers (size and composition of the sample, method of data collection, data analysis methods), the context (time and space) within which have been conducted the different research, not to mention, the evolutionary nature of consumer behavior and shoppers in particular.

\section{Research Methodology}

\subsection{Sample and Data Collection Procedures}

To answer our research question, a face-to-face survey has been conducted on the basis of a sample of 665 shoppers from different age groups and occupational categories.

Selected demographic characteristics of the 600 respondents, including marital status, professional status, educational level and marital status are presented in Table 1.

Table 1. Socio-demographic characteristics of the sample

\begin{tabular}{llll}
\hline Gender & & Professional status & \\
Male & $47 \%$ & Retried & $4 \%$ \\
Female & $53 \%$ & Entrepreneur & $2 \%$ \\
Martial Status & & Liberal Professional & $6 \%$ \\
Single & $44 \%$ & Senior officer & $15 \%$ \\
Married without children & $9 \%$ & Executive & $19 \%$ \\
Married with children & $47 \%$ & Merchant-farmers-craftsman & $8 \%$ \\
Educational level & & Employee & $17 \%$ \\
Primary & $5 \%$ & Student & $15 \%$ \\
Secondary & $35 \%$ & Unemployed & $11 \%$ \\
University & $60 \%$ & Others & $3 \%$ \\
\hline
\end{tabular}

About $41 \%$ of respondents were male, and about $44 \%$ of them were single. A majority of respondents indicated an educational level of a high school degree or more (95\%) or more.

All respondents were interviewed during their shopping visit. The subjects were asked to indicate whether they usually attend one or more stores, to precise their main store visit motivations (price, proximity, accessibility, product selection, quality of products and services, loyalty card), to provide an estimate of the average frequency of shopping from stores as well as the average of the shopping duration, and finally to provide information about their socio-demographic profiles (age, gender, education level, socio-professional category, family status). All these variables were categorical.

\subsection{Data Analysis}

In addition to univariate analysis, allowing the description of the sample and determining the distribution of variables, we used two methods of multivariate analysis: the multiple correspondence analysis and automatic classification. 
Multiple Correspondence Analysis was used to analyze the relationships between qualitative variables of the study and helped to develop a typology of shopping trips. As for the automatic classification, it has been used to compile a typology of shoppers from the four types of shopping trips.

The quality of this classification has been considered from an index of homogeneity estimated from the average distance observations from the center of their respective classes, the standard deviation of the number of individuals in each class and a dispersion index that measures the average distance between the centers of classes.

\section{Results}

The study of the shopping motivations distribution indicates the importance of functional motivations at the expense of experiential motivations (see Table 1). For $59.2 \%$ of shoppers, the price came out as the main motivation of store choice. In addition and since $56.5 \%$ of the shoppers seek proximity and visit the stores closest to home, they seem to frequent the stores by habit. It is also noticeable that the atmosphere of the store motivates only $31.4 \%$ of the surveyed shoppers, while loyalty programs motivate only $26.8 \%$ of them.

Table 2. Shopping motives

\begin{tabular}{ll}
\hline Motivations & $\%$ \\
\hline Price & $59.2 \%$ \\
Proximity & $56.5 \%$ \\
Services' quality & $43.9 \%$ \\
Promotion & $39.7 \%$ \\
By Habit & $39.2 \%$ \\
Atmosphere & $31.4 \%$ \\
Loyality Card & $26.8 \%$ \\
Accessibility & $26.2 \%$ \\
\hline
\end{tabular}

As for the characteristics of shopping trips, we found that the number of frequent trips (more than twice per week) is less important. Unlike the less frequent trips (less than once per month) are more considerable. This indicates that to the majority of the Tunisian shoppers, shopping at the store is often planned. To make urgent or light purchases, many Tunisians still frequent traditional grocers to benefit from other very personal services such as buying on credit.

As for the trips duration, those that last less than one hour are the most common, especially those that last between 30 minutes and 1 hour. Only $8.7 \%$ of shoppers spend more than two hours in stores

It is also noteworthy that nearly two out of three shoppers attend more than one store. This reflects the low loyalty of Tunisian shoppers to stores they usually frequent. This may be due to several reasons such as dissatisfaction, perceived service quality and looking for new spaces for recreational visits.

Regarding the shopping trips typology, the correspondence map (Figure 1) constructed from crossing the motivation variables, trips frequency and trips duration, restores $28.17 \%$ of the total inertia. As shown in Figure 1 and Table 3 , the first factor restores $14.89 \%$ of the total inertia and distinguishes between, on the one hand, the modalities " $2 \mathrm{~h}$ " ( 2 hours) and "twice per month"; and "under 30 min" and "twice per week" on the other hand. The second factor restores $13.28 \%$ of the total inertia and distinguishes between the modalities "over 3 times per week" and "atmosphere" against "between 30 minutes and 1hour" and " 3 times per month". 


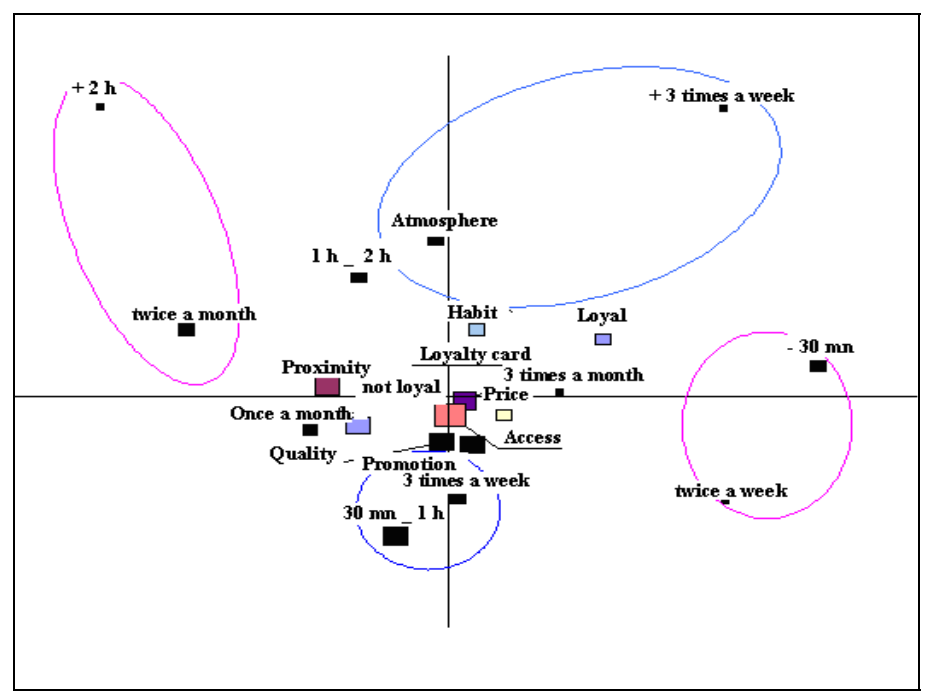

Figure 1. Shopping trips typology

Table 3. Loadings of the main modalities used in the shopping trips typology

\begin{tabular}{lllll}
\hline & \multicolumn{2}{c}{ Factor 1 $(14.89 \%)$} & \multicolumn{2}{c}{ Factor 2 (13.28\%) } \\
\hline Positive & Under 30mm & $+26.91 \%$ & Over three times a week & $+10.66 \%$ \\
loadings & Twice a week & $+10.66 \%$ & Atmosphere & $+15.46 \%$ \\
Negative & Twice a month & $-13.63 \%$ & Between 30mm-1 hour & $-17.62 \%$ \\
loadings & Over 2 hours & $-10.20 \%$ & Three times a month & $-4.97 \%$ \\
\hline
\end{tabular}

The first factor opposes planned shopping trip to fast shopping trip while the second factor opposes recreational shopping behavior to routine shopping trip.

To develop a shopping-trip typology, we conducted an automatic classification from the comparison of 2, 3, 4 and 5 classes' clusters. A typology of four classes proved to be optimal in terms of three indices. The homogeneity index is about 2.76 , the average dispersion between classes has reported a value of 7.8 and standard deviation of the number of individuals in each class is 38.45 .

These findings confirm the existence of four types of shopping trips. The planned-shopping trips having the lowest frequency and the highest duration, recreational shopping trips which occur " 3 times per week" and "the atmosphere" is the most wanted motivation; Light fill-in shopping trips seemed to last the least (under 30 min) and are conducted on average twice a week and ordinary fill-in trip which lasts "between 30 minutes and 1 hour" and also conducted on average " 3 times per month".

A second and final correspondence-factor analysis was conducted from crossing the four categories of shopping and shoppers demographic characteristics (see Figure 2 and Table 4) and led to 4 categories of shoppers. 


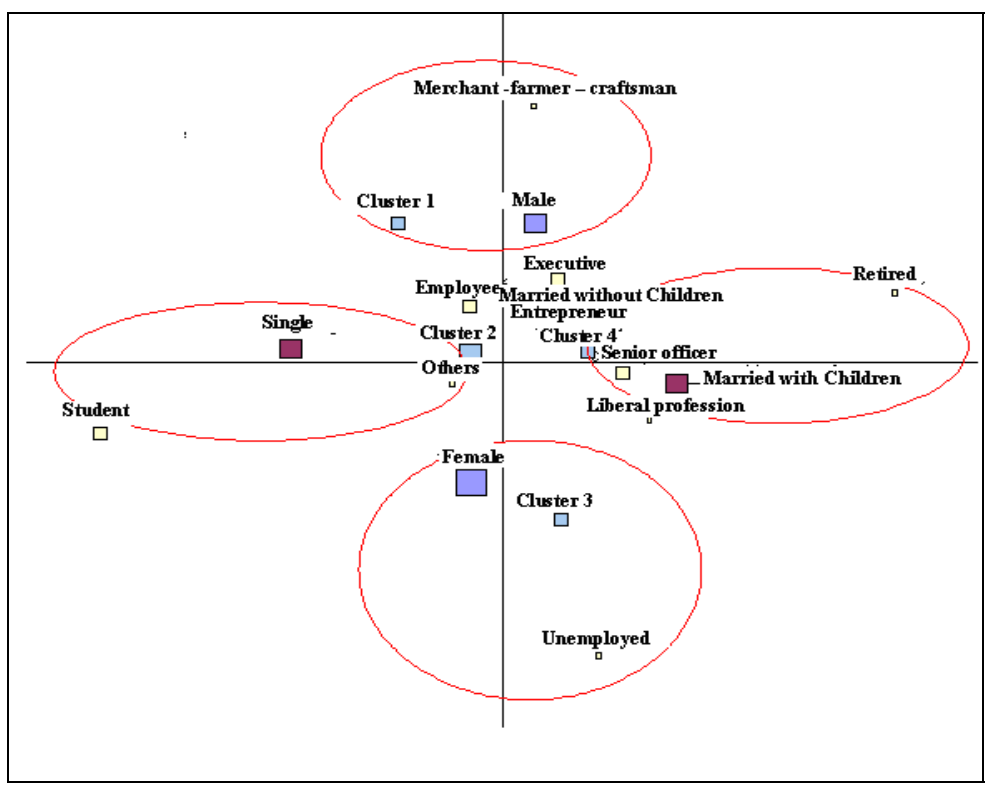

Figure 2. Shoppers' typology

Table 4. Loadings of the main modalities used in the shoppers' typology

\begin{tabular}{lllll}
\hline & \multicolumn{2}{c}{ Factor 1 (14.89\%) } & \multicolumn{2}{c}{ Factor 2 (13.28\%) } \\
\hline Positive & Married with children & $+18.50 \%$ & Over three times a week & $+20.29 \%$ \\
loadings & Retried & $+7.20 \%$ & Atmosphere & $+12.25 \%$ \\
Negative & Student & $-31.33 \%$ & Between 30mm-1 hour & $-21.07 \%$ \\
loadings & Single & $-25.88 \%$ & Three times a month & $-18.04 \%$ \\
\hline
\end{tabular}

The first category represents $9.95 \%$ of the sample. These shoppers are predominantly male, farmers, merchants or craftsmen who regularly adopt ordinary fill-in shopping trips. The second category which represents $28.35 \%$ of the total surveyed shoppers, is composed of single women $/ \mathrm{men}$, often students and adopts light fill-in shopping trips. The third category (34.8\%) includes women without professions and is interested in recreational trips. Finally the fourth category $(26.9 \%)$ is composed of married shoppers with children and retired who planned their shopping trips.

\section{Discussion \& Conclusion}

This research shows that, for the Tunisian shoppers, utilitarian motivations are still predominant in relation to experiential and hedonic motivations and suggests that utilitarian shopping is interesting to the most of the Tunisian shoppers. It has also highlighted the diversity of the shopping behavior of Tunisians and demonstrates that cultural differences explain much of this kind of behavior.

In addition, this research has shown that a two-class typology (major and fill-in shopping trips) is highly reductive of the reality. Indeed, it has highlighted the importance for some shoppers, of the hedonic dimension of the shopping activities and, therefore, suggested the necessary consideration of a "new" category of shopping trips, the recreational shopping trips, increasingly found in recent marketing researchers and which focuses on pleasure, atmosphere, fun and social interaction.

Furthermore, and contrary to what some researchers argue, there are several variants of "fill-in shopping trips". In this research, a distinction is made between "light fill-in shopping trips" and "ordinary fill-in shopping trips". The first category includes very frequent, but fast and light visits, while the second category is less frequent and does not exceed one hour.

Taking into account the shoppers' socio-demographic characteristics, we can give a clearer idea on the shoppers' profile and lead to a better understanding of the shopping behavior.

Singles that are still living with their parents as well as the students with a weak purchasing power are those who are most likely to practice "the light fill-in shopping trip". The housewives with no profession are the most 
interested in the "recreational shopping trip". For budgetary reasons, retired and married people with children are most motivated by "planned shopping behavior". Finally, people belonging to the middle social class (farmers, craftsmen and merchants) adopt the "ordinary fill-in shopping trip".

Besides of its theoretical contribution, this research has also practical value. Our findings could help retailers to a better segmentation of their market, to an optimization of their Customer Relationship Management programs as well as their communication. They have to focus on the hedonic value of the shopping activity when they are communicating with shoppers interested in recreational shopping and to focus on the utilitarian value especially the gain of time when they are dealing with shoppers interested in fill-in shopping.

Note that the fact of the purely exploratory nature of this research, the unrepresentative nature of the sample and the fact of not taking into account some aspects of shopping behavior does not allow extrapolation of results.

Taking into account the customer's value and the recentness of purchases and perhaps other individual shoppers' characteristics can lead to a better understanding of the shopping behavior. Moreover, conducting such research in a cross-cultural perspective will help us to better understand the effect of cultural variables on the shopping behavior.

\section{References}

Anic, I. D., \& Radas, S. (2006). The Impact of Situational Factors on Purchasing Outcomes in the Croatian Hypermarket Retailer. Ekonomski pregled, 57(11), 730-752.

Anic, I. D., \& Vouk, R. (2005). Exploring the Relationships between Store Patronage Motives and Purchasing Outcomes for Major Shopping Trip in the Croatian Grocery Retailing. Ekonomski pregled, 56(9), 634-657.

Arnold, M. J., \& Reynolds, D. E. (2003). Hedonic shopping motivations. Journal of Retailing, 79(2), 77-95. http://dx.doi.org/10.1016/S0022-4359(03)00007-1

Arnold, S., Oum, T. H., \& Tigert, D. J. (1983). Determinant Attributes in Retail Patronage: Seasonal, Temporal, Regional, and International Comparisons. Journal of Marketing Research, 2(20), 149-157. http://dx.doi.org/10.2307/3151681

Babin, B., Darden, W., \& Griffin, M. (1994). Work and/or fun: Measuring hedonic and utilitarian shopping value. Journal of Consumer Research, 20, 644-657. http://dx.doi.org/10.1086/209376

Baker, J., Parasuraman, A., Grewal, D., \& Voss, G. (2002). The Influence of Multiple Store Environment Cues on Perceived Merchandise Value and Store Patronage Intentions. Journal of Marketing, 66, 120-141. http://dx.doi.org/10.1509/jmkg.66.2.120.18470

Bell, D., \& Lattin, J. (1998). Shopping Behavior and Consumer Preference for Store Price Format: Why "Large Basket" Shoppers Prefer EDLP. Marketing Science, 17(1), 66-88. http://dx.doi.org/10.1287/mksc.17.1.66

Bellenger, D. N., \& Korgaonkar, P. K. (1980). Profiling the recreational shopper. Journal of Retailing, 56(3), 77-92.

Bellenger, D. N., Robertson, D. H., \& B. A. Greenberger. (1977). Shopping centers patronage motives. Journal of Retailing, 53(2), 29-38.

Bloch, P. H., \& Richins, M. L. (1983). Shopping Without Purchase: An Investigation of Consumer Browsing Behavior. Advances in Consumer Research, 10, 389-393.

Bloch, P. H., Ridgway, N. M., \& Sherrell, D. L. (1989). Extending the Concept of Shopping: An Investigation of Browsing Activity. Journal of the Academy of Marketing Science, 17(1), 13-21. http://dx.doi.org/10.1007/BF02726349

Bloch, P. H., Ridgway, N. M., \& Nelson, J. E. (1991). Leisure and the Shopping Mall. Advances in Consumer Research, 18, 445-452.

Boedeker, M. (1995). New-type and traditional shoppers: A comparison of two major consumer groups. International Journal of Retail and Distribution Management, 23, 17-26.

Carpenter, J. M., \& Moore, M. (2009). Utilitarian and hedonic shopping value in the US discount sector. Journal of Retailing and Consumer Service, 16, 68-74. http://dx.doi.org/10.1016/j.jretconser.2008.10.002

Carpenter, J. M. (2008). Demographics and patronage motives of supercenter shoppers in the United States. International Journal of Retail \& Distribution Management, 36(1), 5-16.

Cassill, N., \& Williamson, N. (1994). Department store cross-shoppers. Journal of Applied Business Research, 10(4), 88-97. 
Chen, H. S., \& Hsieh, T. (2011). The effect of atmosphere on customer perceptions and customer behavior responses in chain store supermarkets. African Journal of Business Management, 5(24), 54-66.

Crask, M. R., \& Reynolds, F. D. (1978). An In-depth profile of the department store shopper. Journal of Retailing, 54, 23-32.

Darden, W. R. (1980). A patronage model of consumer behavior. In Stampfl, R. W., \& Hirshman, E. (Eds.), Competitive structure in retail markets: The department store perspective. Chicago. American Marketing Association.

Darden, W. R., \& Howell, R. D. (1987). Socialization effects of retail work experience in shopping orientations. Journal of Academy of Marketing and Science, 15(3), 52-63. http://dx.doi.org/10.1007/BF02722171

Darden, W. R., \& Reynolds, F. D. (1971). Shopping orientations and product usage rates. Journal of Marketing Research, 8, 505-508. http://dx.doi.org/10.2307/3150244

Darian, J. C., Tucci, L. A., \& Wiman, A. R. (2001). Perceived Salesperson Service Attributes and Retail Patronage Intentions. International Journal of Retail \& Distribution Management, 29(4-5), 205-213.

Dawson, S., Bloch, P. H., \& Ridgway, N. M. (1990). Shopping motives, emotional states, and Retail outcomes. Journal of Retailing, 66(4), 408-427.

Donovan, R. J., Rossiter, J. R., Marcoolyn, G., \& Nesdale, A. (1994). Store atmosphere and purchasing behavior. Journal of Retailing, 70(3). 283-294. http://dx.doi.org/10.1016/0022-4359(94)90037-X;

Falk, P., \& Campbell, C. (1997). The Shopping Experience. In Falk, P., \& Campbell, C. (Eds.), Sage Publications, London.

Fox, E. J., Montgomery, A. L., \& Lodish, L. M. (2004). Consumer Shopping and Spending across Retail Formats. The Journal of Business, 77(2), s25-s60. http://dx.doi.org/10.1086/381518.

Geuens, M., Brengman, M. S., \& Jegers, R. (2001). An exploratory study of grocery shopping motivations. European Advances in Consumer Research, 5, 135-140.

González-Benito, O., C. A. Bustos-Reyes \& P. A. Muños-Gallego. (2007). Isolating the Geodemographic Characterisation of Retail Format Choice from the Effects of Spatial Convenience. Marketing Letters, 18(1-2), 45-59. http://dx.doi.org/10.1007/s11002-006-9000-z.

Groeppel-Klein, A., Thelen, E., \& Antretter, C. (1999). The impact of shopping motives on store assessment. European Advances in Consumer Research, 4, 63-72.

Guido, G. (2006). Shopping Motives, Big Five Factors, and the Hedonic/Utilitarian Shopping Value: An Integration and Factorial Study. Innovative Marketing, 2(2), 57-67.

Gutman, J., \& Mills, M. K. (1982). Fashion lifestyle, self concept, shopping orientation and store patronage: An integrative analysis. Journal of Retailing, 58(2), 64-86.

Hansen, T. (2003). Intertype competition: speciality food stores competing with supermarkets. Journal of Retailing and Consumer Services, 10(1), 35-49. http://dx.doi.org/10.1016/S0969-6989(01)00038-8

Hassan, Y., Muhammad, N. M. N., \& Abu Bakar, H. (2010). Influence of Shopping Orientation and Store Image on Patronage of Furniture Store. International Journal of Marketing Studies, 2(1), 175-184.

Homer, P. M., \& Kahle, L. R. (1988). A structural equation test of the value-attitude-behavior hierarchy. Journal of Personality and Social Psychology, 54, 638-646. http://dx.doi.org/10.1037/0022-3514.54.4.638

Ibrahim, M. F., \& Wee, Ng. C. (2002). The Importance of Entertainment in the Shopping Centre Experience: Evidence from Singapore. Journal of Real Estate Portfolio Management, 8(3), 239-253.

Jianfeng, Hongping \& Lanying. (2009). The Effect of Religiosity on Shopping Behavior: An Exploratory Study during the Transitional Period in China in ICIII '09 Proceedings of the 2009 International Conference on Information Management. Innovation Management and Industrial Engineering, 2, 31-34. http://dx.doi.org/10.1109/ICIII.2009.165

Jones, M. A., Reynolds, K. E., \& Arnold, M. J. (2006). Hedonic and uyilitarian shopping value: Investigating differential effects on retail outcomes. Journal of Business Research, 59, 974-981. http://dx.doi.org/10.1016/j.jbusres.2006.03.006

Kahn, B. E., \& Schmittlein, D. C. (1989). Shopping Trip Behavior: An Empirical Investigation. Marketing Letters, 1(1), 55-69. http://dx.doi.org/10.1007/BF00436149 
Kahn, B. E., \& Schmittlein, D. C. (1992). The Relationship between Purchases Made on Promotion and Shopping Trip Behavior. Marketing Letters, 68(3), 294-315.

Kaltcheva, V., \& Weitz, B. A. (2006). When Should a Retailer Create an Exciting Store Environment? Journal of Marketing, 70, 107-118. http://dx.doi.org/10.1509/jmkg.2006.70.1.107

Karande, K., \& Ganesh, J. (2000). Who shops at factory outlets and why? An exploratory study. Journal of Marketing Theory \& Practice, 8(4), 29-42.

Kim, H. S. (2006). Using hedonic and utilitarian shopping motivations to profile inner city consumers. Journal of Shopping Center Research, 13(1), 57-79.

Kollat, D. T., \& R. P. Willett Ronald. (1967). Customer Impulse Purchasing Behavior. Journal of Marketing Research, 4(1), 21-3. http://dx.doi.org/10.2307/3150160.

Kolodinsky, J., \& Cranwell, M. (2000). The Poor Pay More? Now They Don't Even Have a Store to Choose From: Bringing a Supermarket Back to the City. Consumer Interests Annual, 46, 24-9.

Kuruvilla, S. J., \& Joshi, N. (2010). Influence of demographics, psychographics, shopping orientation, mall shopping attitude and purchase patterns on mall patronage in India. Journal of Retailing and Consumer Services, 17, 259-269. http://dx.doi.org/10.1016/j.jretconser.2010.02.003

Lesser, J. A., \& Hughes, M. A. (1986). Towards a typology of shoppers. Business Horizons, 29(6), 56-62. http://dx.doi.org/10.1016/0007-6813(86)90038-8

MacInnis, D. J., \& L. L. Price. (1987). The Role of Imagery in Information Processing: Review and Extensions. The Journal of Consumer Research, 13(4), 473-491. http://dx.doi.org/10.1086/209082

Martínez, E., \& Montaner, T. (2006). The effect of consumer's psychographic variables upon dealproneness. Journal of Retailing and Consumer Services, 13(3), 157-168. http://dx.doi.org/10.1016/j.jretconser.2005.08.001

Miller, C. E., Reardon, J., \& McCorkle, D. E. (1999). The effects of competition on retail structure: an examination of intratype, and intercategory competition. Journal of Marketing, 63, 107-120. http://dx.doi.org/10.2307/1251977

Mokhlis, S. (2006). The Effect of Religiosity on Shopping Orientation: An Exploratory Study in Malaysia. Journal of American Academy of Business, 9(1), 64-74. Cambridge. Hollywood.

Morganosky, M. A. (1997). Retail Market Structure Change: Implications for Retailers and Consumers. International Journal of Retail Distribution and Management, 25(8), 269-274.

Moschis, G. P., Curasi, C., \& Bellenger, D. (2004). Patronage motives of mature consumers in the selection of food and grocery stores. Journal of Consumer Marketing, 21(2), 123-133.

Nordfalt, J. (2009). Unplanned Grocery Purchases: The Influences of the Shopping Trip Type Revisited. Journal of Consumer Behaviour, 8(1), 1-13. http://dx.doi.org/10.1002/cb.269

Oates, B., Shufeldt, L., \& Vaught, B. (1996). A psychographic study of the elderly and retail store attributes. Journal of Consumer Marketing, 13(6), 14-27.

Reynolds, Kristy \& Sharon Beatty. (1999). A Relationship Customer Typology. Journal of Retailing, 75, 509-523. http://dx.doi.org/10.1016/S0022-4359(99)00016-0

Rhee, Y. S., \& Jeon. J. H. (2001). A Study on the Relationship between Service Quality of Apparel Stores and Related Variables. Journal of the Korean Society of Clothing and Textiles, 25(6), 1057-1068.

Seiders, K., \& Tigert, D. J. (2000). The Impact of Supercenters on Traditional Food Retailers in Four Markets. International Journal of Retail \& Distribution Management, 28, 181-193.

Shim, S., \& Eastlick, M. A. (1998). The hierarchical influence of personal values on mall shopping attitude and behavior. Journal of Retailing, 74(1), 139-60. http://dx.doi.org/10.1016/S0022-4359(99)80091-8.

Shim, S., \& Kotsiopulos, A. (1992). Patronage behavior of apparel shopping: Part II. Testing a patronage model of consumer behavior. Clothing and Textile Research Journal, 10, 58-64. http://dx.doi.org/10.1177/0887302X9201000209

Skallerud, K., Korneliussen, T., \& Olsen, S. V. (2009). An Examination of Consumers' Cross-Shopping Behaviour. Journal of Retailing and Consumer Services, 16(3), 181-189. http://dx.doi.org/10.1016/j.jretconser.2008.11.012. 
Swanson, K. K. (2004). Tourists' and retailers' perceptions of souvenirs. Journal of Vacation Marketing, 10, 363-377. http://dx.doi.org/10.1177/135676670401000407

Swinyard, W. R. (1998). Shopping Mall Customer Values: The National Mall Shopper and the List of Values. Journal of Retailing and Consumer Services, $167-172$. http://dx.doi.org/10.1016/S0969-6989(97)00023-4

Tauber, E. M. (1972). Why do people shop? Journal of Marketing, 36, 46-59. http://dx.doi.org/10.2307/1250426

Visser, E. M., \& Du Preez, R. (2001). Apparel shopping orientation: Two decades of research. Journal of Family Ecology and. Consumer Sciences, 29, 72-81.

Walters, R. G., \& M. Jamil. (2003). Exploring the relationships between shopping trip type, purchases of products on promotion, and shopping basket profit. Journal of Business Research, 56(1), 17-29. http://dx.doi.org/10.1016/S0148-2963(01)00201-6

Westbrook, R., \& W. C. Black. (1985). A Motivation-Based Shopper Typology. Journal of Retailing, 61, 78-103. 